\title{
BEHAVIOUR, HABITAT USE AND POPULATION SIZE OF Sotalia fluviatilis (GERVAIS, 1853) (CETACEA, DELPHINIDAE) IN THE CANANÉIA ESTUARY REGION, SÃO PAULO, BRAZIL
}

\author{
GEISE, L., ${ }^{1}$ GOMES, N. ${ }^{2}$ and CERQUEIRA, R. ${ }^{3}$ \\ ${ }^{1}$ Setor de Zoologia, DBAV, Instituto de Biologia, Universidade do Estado do Rio de Janeiro, Rua São Francisco \\ Xavier, 524, Maracanã, CEP 20550-013, Rio de Janeiro, RJ, Brazil \\ ${ }^{2}$ Museu de Zoologia, Universidade de São Paulo, C.P. 7172, CEP 01064-970, São Paulo, SP, Brazil \\ ${ }^{3}$ Departamento de Ecologia, Instituto de Biologia, Universidade Federal do Rio de Janeiro, Cidade Universitária, \\ C.P. 68020, CEP 21941-590, Rio de Janeiro, RJ, Brazil \\ Correspondence to: Lena Geise, Setor de Zoologia, DBAV, Instituto de Biologia, Universidade do Estado do Rio de \\ Janeiro, Rua São Francisco Xavier, 524, Maracanã, \\ CEP 20550-013, Rio de Janeiro, RJ, Brazil, e-mail: geise@uerj.br \\ Received May 30, 1997 - Accepted September 4, 1998 - Distributed June 30, 1999
}

(With 5 figures)

\begin{abstract}
From March 1987 to February 1988, Sotalia fluviatilis population size was estimated and behavioral patterns were observed in the Cananéia estuary region, in Southeast Brazil. Field observations were carried out from shore (40, with a mean observation period of $7.76 \pm 2.05$ hours a day, completing a total of 310.5 hours) and during line transect surveys by boat $(55,10$ of them with a mean observation period of $4.44 \pm 0.15$ hours each and 45 with a mean observation time of 20 minutes, in the totality 64.3 hours).

Dolphins occur in this region all year round, most commonly in small groups, with a greater number observed in January 1988, with no seasonal occurrence pattern. Pairs accounted for $c a$. $30 \%$ and calves were seen year round, always accompanied by one or more adults. Juveniles were slightly more common from July to February. More dolphins were seen from 9:00 a.m. to 10:00 a.m. (60.8\%) until midday. From fourteen behavioral patterns identified, travelling $(46.8 \%)$ and feeding $(33.9 \%)$ were the most frequently observed. Group size and composition differed in each behavioral pattern. Diurnal migration was observed, related with hour and not to tide conditions. Dolphins were seen throughout the estuary.

For the whole survey area, population density ( $\hat{D}$ ) was $3.38 \pm 1.76$ individuals $/ \mathrm{km}^{2}$, dolphin abundance was found to be $704.8 \pm 367.7$ along 10 line transect from April 1987 from, where $82 \mathrm{~km}$ were surveyed. In Trapandé Bay, the largest part of the studied area, D equaled $12.4 \pm 10.3$ individuals/ $\mathrm{km}^{2}$ in the morning and $16.4 \pm 13.8$ individuals $/ \mathrm{km}^{2}$ in the afternoon.
\end{abstract}

Key words: Sotalia fluviatilis, habitat use, population estimation, behavioral patterns.

\section{RESUMO}

\section{Behavior, habitat use and population size of Sotalia fluviatilis}

De março de 1987 a fevereiro de 1988, foi estudada uma população de Sotalia fluviatilis da região estuarina lagunar de Cananéia, no litoral sudeste do Brasil. Padrões comportamentais foram observados e o tamanho populacional foi estimado. Foram realizadas 40 observações em pontos fixos (média de $7,76 \pm 2,05$ horas de observação cada, num total de 310,5) e através de 55 transectos lineares de barco (10 com 4,43 \pm 0,15 horas de duração média cada e 45 com 20 minutos de duração média cada, totalizando 64,3 horas). Os golfinhos foram vistos nessa região ao longo de todo o ano, com um aumento no número de espécimens em janeiro de 1988, não mostrando um padrão sazonal. Usualmente, estive- 
ram presentes em grupos pequenos, sendo os pares os mais freqüentes (ca. 30\%). Filhotes também ocorreram ao longo de todo o ano, sempre acompanhados de um ou mais adultos. Jovens foram mais freqüentes entre julho e fevereiro. A maior quantidade de golfinhos foi vista entre 9 e 10 horas, completando 60,8\% das observações até as 12 horas. Foram identificados 14 padrões comportamentais, sendo os padrões de deslocamento $(46,8 \%)$ e de pesca $(33,9 \%)$ os mais freqüentes. O tamanho do grupo e sua composição diferiram de acordo com cada padrão comportamental. Migrações diurnas foram observadas, com uma preferência horária e não relacionada às condições de maré. Os golfinhos foram vistos em todas as áreas da região estuarina. Para a área amostrada através dos 10 transectos lineares de maior duração, com $82 \mathrm{~km}$ de extensão (percorridos uma vez ao mês a partir de abril de 1987), a densidade populacional ( $\hat{\mathrm{D}}$ ) foi de $3,35 \pm 1,76$ indivíduos $/ \mathrm{km}^{2}$, sendo o número total estimado de $704,8 \pm 367,7$. Na Baía de Trapandé, a área mais larga da região estudada, D̂ foi de 12,4 \pm 10,3 golfinhos $/ \mathrm{km}^{2}$, durante a parte da manhã, e de 16,4 $\pm 13,8$ golfinhos $/ \mathrm{km}^{2}$, durante a tarde.

Palavras-chave: Sotalia fluviatilis, utilização de hábitat, estimativa populacional, padrões comportamentais.

\section{INTRODUCTION}

The common South American dolphin Sotalia fluviatilis, also named "boto" in the south-eastern coast of Brazil, has been subject of interest in the last 15 years (Silva \& Best, 1994). Reports on its distribution (Borobia et al., 1991) and feeding habits (Silva, 1983) have included the freshwater form of the genus, while a comprehensive review on Sotalia has been recently published (Silva \& Best, 1994, 1996).

The known distribution of marine $S$. fluviatilis extends from Santa Catarina Island, Brazil (273'서, 48³4'W) (Simões-Lopes, 1988) to Honduras $\left(15^{\circ} 58^{\prime} \mathrm{N}, 85^{\circ} 42^{\prime} \mathrm{W}\right)$, in an apparently continuous fashion (Borobia et al., 1991; Silva \& Best, 1994, 1996). Geise (1991) described S. fluviatilis population and behavior in Guanabara Bay, Rio de Janeiro, and additional data on morphology and feeding habits in the Cananéia region have been reported (Schmiegelow, 1990).

In this paper, we report observations on a local population of $S$. fluviatilis, presenting data on seasonal, monthly and daily occurrence, movement patterns, behavior, and some ecological aspects in the Cananéia estuary-lagunar region on the Southern coast of São Paulo State.

\section{MATERIAL AND METHODS}

Dolphins were observed in the Cananéia region (Fig. 1) during some continuous days per month, from March 1987 through February 1988, for at least 5.7 hours per day (Tables 1 and 2). Observations, using the "all occurrence" method (Lehner, 1979) were made either from shore or from a $4 \mathrm{~m}$ long metallic boat, consisting in counting all observed animals because individual identification was not possible, conducted by one observer (L. Geise).

At boat, they were made from prow, using binoculars to count distant groups and with naked eyes for short distances. From the shore station on Cardoso Island (Fig. 1) observations were carried out with binoculars, group size and composition, time of sighting, diving duration for each behavior and association with other species were recorded. Tide predictions were based on the Brazilian Navy tide tables for the Paranaguá harbor, ca. $70 \mathrm{~km}$ away from the study area.

Ten line transect surveys were conducted each month around Cananéia Island, from April 1987 to January 1988 aboard the boat at constant speed (ca. $15 \mathrm{~km} / \mathrm{h}$; Table 2). A total of $82 \mathrm{~km}$ per trip was covered (Fig. 1), without stopping or approaching the dolphins. Each survey lasted approximately uninterrupted 4.5 hours. This method minimized the chance of double counting animals and thus overestimating population density. Two other short transects of $6 \mathrm{~km}$ each, were occasionally made, whenever visibility conditions permitted, between Cananéia and Cardoso Islands, before and after the shore observation period (Fig. 1; Table 2). These transects occurred in the morning, and afternoon, with a total of 45 surveys being conducted. 


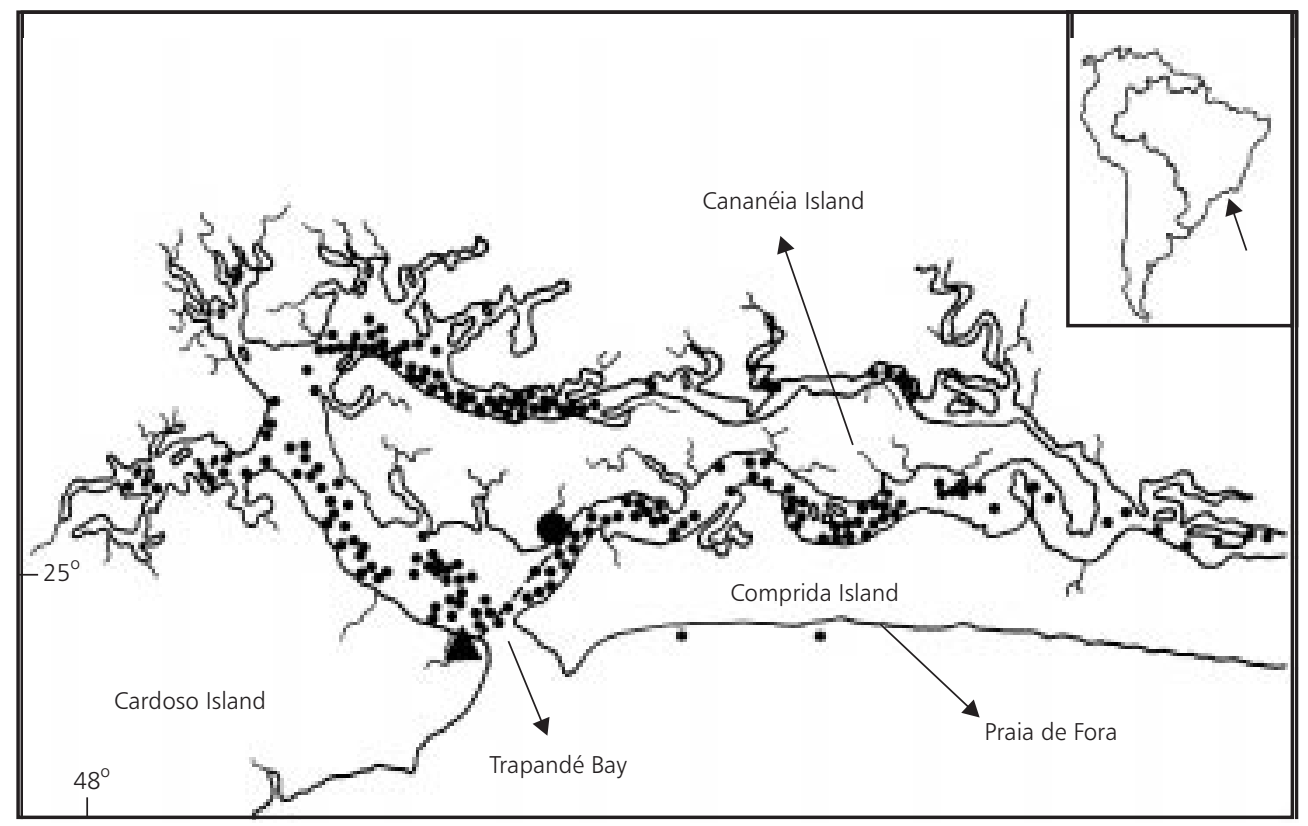

Fig. 1 - Study area (Cananéia estuarine region). Shore observation point (triangle); Cananéia City (dot); short line transect trajectory (dashed line). Black dots indicates places where groups were seen.

Population estimates were based on the procedure of Smith (1981): moving in a constant speed $(15 \mathrm{~km} / \mathrm{h})$, dolphins were counted up to $90^{\circ}$ $(\theta)$ right and left from trackline. The shortest distance from the boat to the sighted object (R) was estimated visually. All these basic information were used to estimate the perpendicular sighting distance, $\mathrm{y}(\mathrm{y}=\mathrm{R} \sin \theta)$.

The equation to estimate density was $\hat{\mathrm{D}}=(\mathrm{n}-$ 1) $/ 2 y L(\hat{D}=$ density; $L=$ total track length) and the variance of $\hat{\mathrm{D}}$ was obtained by $\mathrm{V}(\hat{\mathrm{D}})=$ $\hat{\mathrm{D}}^{2} / \mathrm{n} \cdot 2(\mathrm{n}-1) / \mathrm{n}-2-\mathrm{n} / \hat{\mathrm{D} A}(\mathrm{~A}=$ total area). And to obtain the total number, we used $\mathrm{N}=\hat{\mathrm{D}} \cdot \mathrm{A}$. In each hourly interval the number of seen dolphins was divided by the number of observed hours.

Specimens were identified as adults, juveniles and calves, according to size and color patterns by visual estimation, not using any kind of optical device; juveniles measuring $1 / 2$ to $3 / 4$ of adults, and calves not reaching more than $1 / 4$ th of adult length and with a grey-rosy color (Silva \& Best, 1996; Schmiegelow, 1990; Simões-Lopes, 1988; Carvalho, 1963). Groups were defined as parties swimming together, with members not necessarily swimming in the same direction at the same time. As no survey was made during December 1987, two were carried out during January 1988, at the beginning and at the end of the month. Chi-square tests were used to verify the significance of differences between data (frequency of dolphin's presence and behavior with time and months). For correlation analysis we used the non parametric Spearman Correlation (r) (Zar, 1984).

\section{RESULTS}

\section{Periodicity of occurrence}

Dolphins were seen from shore and from boat in Trapandé Bay and around Cananéia Island all year round (Figs. 1 and 2); their presence not being constant during all months $\left(\mathrm{X}_{11}^{2}=12.44 ; \mathrm{P}<0.05\right)$. Few dolphins were observed in September $(0.96$ individuals/hour) while a greater number were recorded during the second observation period of January 1988 (17.34 individuals/hour). When these results were analyzed by season, no differences were obser$\operatorname{ved}\left(\mathrm{X}_{3}^{2}=5.13 ; \mathrm{P}<0.05\right)$. Although dolphins were present at the study site all year round, it was not possible to know if these animals were the same during all seasons as individuals could not be identified. Only 3 dolphins $(0.1 \%)$ were identified by scarring patterns from October 1987 to January 1988. 
TABLE 1

Observation effort from shore in the Cananéia estuarine region.

\begin{tabular}{|c|c|c|c|}
\hline $\begin{array}{l}\text { Month/Day/ } \\
\text { Year }\end{array}$ & $\begin{array}{l}\text { Beginning of } \\
\text { observation }\end{array}$ & $\begin{array}{c}\text { Ending of } \\
\text { observation }\end{array}$ & $\begin{array}{c}\text { Total observed hours } \\
\text { (hour:minutes) }\end{array}$ \\
\hline $03 / 24 / 87$ & $17: 00$ & $18: 00$ & $1: 00$ \\
\hline $03 / 25 / 87$ & $8: 40$ & $16: 00$ & $7: 20$ \\
\hline $03 / 26 / 87$ & 13:00 & $18: 00$ & 5:00 \\
\hline $04 / 23 / 87$ & 8:00 & $16: 00$ & $8: 00$ \\
\hline $04 / 24 / 87$ & $16: 00$ & $18: 00$ & $2: 00$ \\
\hline $04 / 26 / 87$ & $9: 30$ & 18:00 & $8: 30$ \\
\hline $04 / 27 / 87$ & $8: 30$ & $12: 30$ & 4:00 \\
\hline $05 / 27 / 87$ & 8:00 & $15: 50$ & $7: 50$ \\
\hline $05 / 28 / 87$ & $14: 15$ & $16: 30$ & $2: 15$ \\
\hline $05 / 29 / 87$ & $14: 00$ & $17: 30$ & $3: 30$ \\
\hline $05 / 30 / 87$ & $7: 45$ & $15: 30$ & $7: 45$ \\
\hline $06 / 22 / 87$ & $17: 30$ & $18: 00$ & $0: 30$ \\
\hline $06 / 23 / 87$ & $6: 30$ & $17: 30$ & 11:00 \\
\hline $06 / 24 / 87$ & $8: 00$ & $17: 30$ & $9: 30$ \\
\hline $06 / 25 / 87$ & $8: 20$ & $16: 20$ & 8:00 \\
\hline $07 / 27 / 87$ & $7: 50$ & $16: 40$ & $8: 50$ \\
\hline $07 / 28 / 87$ & $7: 30$ & $17: 30$ & $10: 00$ \\
\hline $07 / 29 / 87$ & $7: 15$ & $12: 00$ & $4: 45$ \\
\hline $07 / 30 / 87$ & 8:00 & $14: 05$ & $6: 05$ \\
\hline $08 / 25 / 87$ & $7: 45$ & $15: 35$ & $7: 50$ \\
\hline $08 / 26 / 87$ & $7: 35$ & $17: 00$ & $9: 25$ \\
\hline $09 / 21 / 87$ & $6: 30$ & $18: 00$ & $11: 30$ \\
\hline $09 / 22 / 87$ & $6: 30$ & $12: 00$ & $5: 30$ \\
\hline $10 / 27 / 87$ & $6: 45$ & $17: 00$ & $10: 15$ \\
\hline $10 / 28 / 87$ & $6: 30$ & $16: 15$ & $9: 45$ \\
\hline $10 / 29 / 87$ & $13: 00$ & $17: 30$ & $4: 30$ \\
\hline $10 / 30 / 87$ & $6: 40$ & $17: 00$ & $10: 20$ \\
\hline $11 / 16 / 87$ & $7: 15$ & $17: 00$ & $9: 45$ \\
\hline $11 / 17 / 87$ & 7:00 & $17: 10$ & $10: 00$ \\
\hline $11 / 19 / 87$ & $6: 45$ & $16: 40$ & 9:55 \\
\hline $11 / 20 / 87$ & $6: 45$ & $17: 00$ & $10: 15$ \\
\hline 01/04/88 & $6: 50$ & $16: 50$ & $10: 00$ \\
\hline 01/05/88 & $6: 45$ & $16: 50$ & $10: 05$ \\
\hline $01 / 25 / 88$ & $7: 30$ & $17: 00$ & 9:30 \\
\hline $01 / 26 / 88$ & $7: 20$ & $17: 00$ & $9: 40$ \\
\hline $01 / 28 / 88$ & 7:00 & $17: 00$ & 10:00 \\
\hline $01 / 29 / 88$ & $7: 00$ & $17: 00$ & 10:00 \\
\hline $02 / 29 / 88$ & 7:00 & $17: 05$ & $10: 05$ \\
\hline 03/01/88 & 7:00 & $17: 00$ & 10:00 \\
\hline $03 / 03 / 88$ & $6: 45$ & $13: 10$ & $6: 25$ \\
\hline
\end{tabular}


TABLE 2

Observation effort during transects in the Cananéia estuarine region.

\begin{tabular}{|c|c|c|c|c|}
\hline Month/Day/Year & $\begin{array}{l}\text { Beginning of } \\
\text { transect }\end{array}$ & $\begin{array}{c}\text { Ending of } \\
\text { transect }\end{array}$ & $\begin{array}{c}\text { Each transect } \\
\text { duration } \\
\text { (hour:minutes) }\end{array}$ & $\begin{array}{c}\text { Each day transect } \\
\text { duration } \\
\text { (hour:minutes) }\end{array}$ \\
\hline $04 / 24 / 87$ & $7: 30$ & $11: 30$ & 4:00 & $4.00 *$ \\
\hline $04 / 27 / 87$ & $\begin{array}{r}7: 30 \\
13: 00\end{array}$ & $\begin{array}{r}8: 30 \\
13: 20\end{array}$ & $\begin{array}{l}1: 00 \\
0: 20\end{array}$ & 1.20 \\
\hline $05 / 27 / 87$ & $\begin{array}{r}7: 30 \\
15: 50\end{array}$ & $\begin{array}{r}8: 00 \\
16: 20\end{array}$ & $\begin{array}{l}0: 30 \\
0: 30\end{array}$ & 1.00 \\
\hline $05 / 28 / 87$ & 8:00 & $11: 30$ & $3: 30$ & $3.30 *$ \\
\hline $05 / 30 / 87$ & $\begin{array}{r}7: 30 \\
15: 40\end{array}$ & $\begin{array}{r}7: 45 \\
16: 00\end{array}$ & $\begin{array}{l}0: 15 \\
0: 20\end{array}$ & 0.35 \\
\hline $06 / 25 / 87$ & $\begin{array}{r}7: 50 \\
16: 20\end{array}$ & $\begin{array}{r}8: 20 \\
16: 40\end{array}$ & $\begin{array}{l}0: 30 \\
0: 20\end{array}$ & 0.50 \\
\hline $06 / 26 / 87$ & $9: 45$ & $13: 45$ & $4: 00$ & $4.00 *$ \\
\hline $07 / 27 / 87$ & $\begin{array}{r}7: 25 \\
16: 40\end{array}$ & $\begin{array}{r}7: 45 \\
17: 00\end{array}$ & $\begin{array}{l}0: 20 \\
0: 20\end{array}$ & 0.40 \\
\hline $07 / 28 / 87$ & $\begin{array}{r}7: 10 \\
17: 40\end{array}$ & $\begin{array}{r}7: 25 \\
18: 15\end{array}$ & $\begin{array}{l}0: 15 \\
0: 35\end{array}$ & 0.50 \\
\hline $07 / 29 / 87$ & $14: 00$ & $17: 40$ & $3: 40$ & $3.40 *$ \\
\hline $07 / 30 / 87$ & $7: 40$ & $8: 00$ & $0: 20$ & 0.20 \\
\hline $08 / 25 / 87$ & $\begin{array}{r}7: 30 \\
16: 00\end{array}$ & $\begin{array}{r}7: 50 \\
16: 20\end{array}$ & $\begin{array}{l}0: 20 \\
0: 20\end{array}$ & 0.40 \\
\hline $08 / 26 / 87$ & $\begin{array}{r}7: 20 \\
17: 00\end{array}$ & $\begin{array}{r}7: 40 \\
17: 10\end{array}$ & $\begin{array}{l}0: 20 \\
0: 10\end{array}$ & 0.30 \\
\hline $08 / 27 / 87$ & $8: 00$ & $14: 00$ & $6: 00$ & $6.00 *$ \\
\hline $10 / 27 / 87$ & $\begin{array}{r}6: 20 \\
16: 50\end{array}$ & $\begin{array}{r}6: 40 \\
17: 10\end{array}$ & $\begin{array}{l}0: 20 \\
0: 20\end{array}$ & 0.40 \\
\hline $10 / 28 / 87$ & $\begin{array}{r}6: 20 \\
16: 20\end{array}$ & $\begin{array}{r}6: 30 \\
16: 40\end{array}$ & $\begin{array}{l}0: 10 \\
0: 20\end{array}$ & 0.30 \\
\hline $10 / 29 / 87$ & 8:00 & $12: 20$ & $4: 20$ & $4.20 *$ \\
\hline $10 / 30 / 87$ & $\begin{array}{r}6: 30 \\
17: 00\end{array}$ & $\begin{array}{r}6: 40 \\
17: 15\end{array}$ & $\begin{array}{l}0: 10 \\
0: 15\end{array}$ & 0.25 \\
\hline $11 / 16 / 87$ & $\begin{array}{r}7: 00 \\
17: 00 \\
\end{array}$ & $\begin{array}{r}7: 15 \\
17: 15 \\
\end{array}$ & $\begin{array}{l}0: 15 \\
0: 15 \\
\end{array}$ & 0.30 \\
\hline $11 / 17 / 87$ & $\begin{array}{r}6: 45 \\
17: 10 \\
\end{array}$ & $\begin{array}{r}7: 00 \\
17: 40 \\
\end{array}$ & $\begin{array}{l}0: 15 \\
0: 30 \\
\end{array}$ & 0.45 \\
\hline $11 / 18 / 87$ & $7: 30$ & $12: 30$ & $5: 00$ & $5.00 *$ \\
\hline $11 / 19 / 87$ & $\begin{array}{r}6: 30 \\
16: 40\end{array}$ & $\begin{array}{r}6: 45 \\
17: 00\end{array}$ & $\begin{array}{l}0: 15 \\
0: 20\end{array}$ & 0.35 \\
\hline $11 / 20 / 87$ & $6: 30$ & $6: 45$ & $0: 15$ & 0.15 \\
\hline $01 / 04 / 88$ & $\begin{array}{r}6: 35 \\
16: 50\end{array}$ & $\begin{array}{r}6: 50 \\
17: 05\end{array}$ & $\begin{array}{l}0: 15 \\
0: 15\end{array}$ & 0.30 \\
\hline $01 / 05 / 88$ & $\begin{array}{r}6: 30 \\
16: 55 \\
\end{array}$ & $\begin{array}{r}6: 40 \\
17: 10 \\
\end{array}$ & $\begin{array}{l}0: 10 \\
0: 15 \\
\end{array}$ & 0.25 \\
\hline $01 / 06 / 88$ & $6: 40$ & 12:00 & $5: 20$ & $5.20 *$ \\
\hline $01 / 25 / 88$ & 17:00 & $17: 20$ & $0: 20$ & 0.20 \\
\hline $01 / 26 / 88$ & $\begin{array}{r}6: 55 \\
17: 05 \\
\end{array}$ & $\begin{array}{r}7: 10 \\
17: 20 \\
\end{array}$ & $\begin{array}{l}0: 15 \\
0: 15 \\
\end{array}$ & 0.30 \\
\hline $01 / 27 / 88$ & $7: 30$ & $11: 45$ & $4: 15$ & $4.15 *$ \\
\hline $01 / 28 / 88$ & $\begin{array}{r}6: 40 \\
17: 00\end{array}$ & $\begin{array}{r}7: 00 \\
17: 20\end{array}$ & $\begin{array}{l}0: 20 \\
0: 20\end{array}$ & 0.40 \\
\hline $01 / 29 / 88$ & $\begin{array}{r}6: 35 \\
17: 00\end{array}$ & $\begin{array}{r}6: 50 \\
17: 20\end{array}$ & $\begin{array}{l}0: 15 \\
0: 20\end{array}$ & 0.35 \\
\hline $02 / 29 / 88$ & $\begin{array}{r}6: 30 \\
17: 10 \\
\end{array}$ & $\begin{array}{r}6: 50 \\
17: 25 \\
\end{array}$ & $\begin{array}{l}0: 20 \\
0: 15 \\
\end{array}$ & 0.35 \\
\hline $03 / 01 / 88$ & $6: 30$ & $6: 50$ & $0: 20$ & 0.20 \\
\hline $03 / 02 / 88$ & $7: 45$ & $12: 00$ & $4: 15$ & $4.15 *$ \\
\hline $03 / 03 / 88$ & $6: 00$ & $6: 40$ & $0: 40$ & 0.40 \\
\hline
\end{tabular}

* Trancerte armund rananáia Icland 


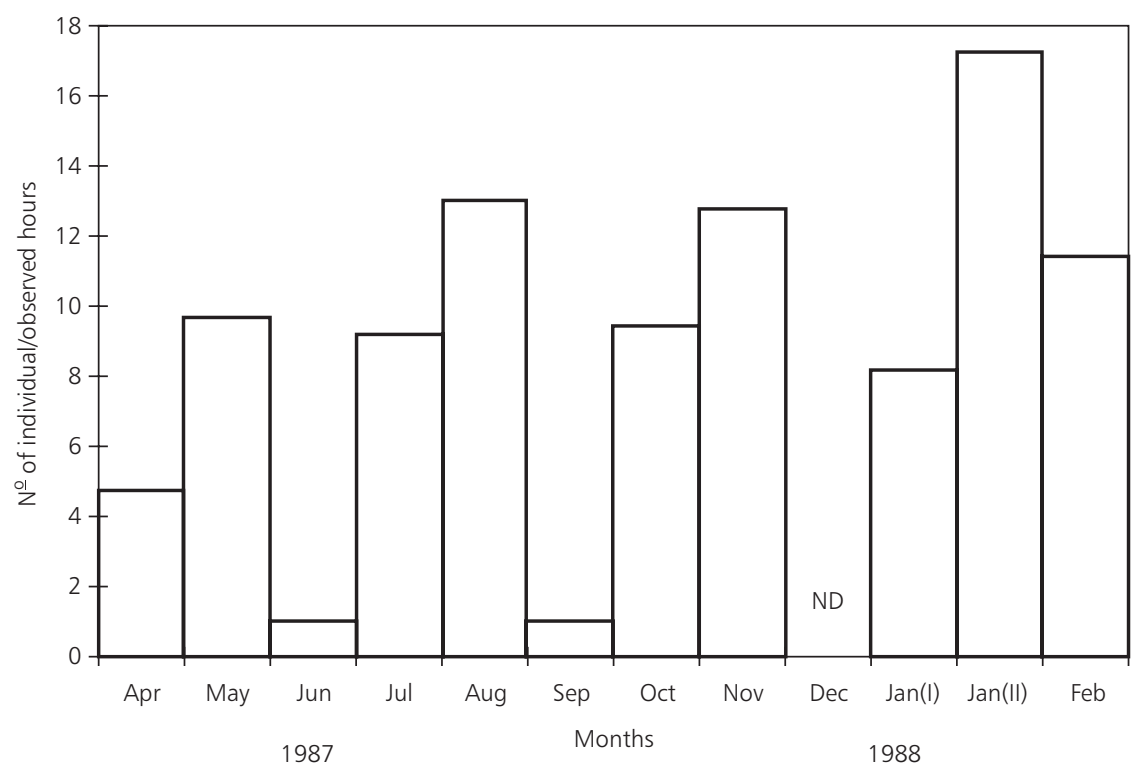

Fig. 2 - Sotalia fluviatilis occurrence in Cananéia estuary from March 1987 to February 1988. ND = no observation. For January (I) and (II) explanation, see Material and Methods.

Small groups, consisting of two to five individuals, were the most commonly observed; pairs accounted for approximately $30 \%$ of all observed groups.

Eighty nine calves were seen almost all year round in an unequal frequency $(75.3 \%$ from October 1987 to February 1988), while juveniles (68 individuals) were more common in July ( 0.3 individuals/hour), August (0.34 individuals/hour) and continuously from October 1987 to February 1988 (0.1 individuals/hour), showing an irregular distribution $\left(\mathrm{X}_{11}^{2}=1.4 ; \mathrm{P}<0.05\right)$. Juveniles were either seen as singles or as part of a group of adults, while calves were always accompanied by one or more adults. Mixed groups, with adults, juveniles, and calves were not usual. The most frequent group composition with calves included one adult and one calf $(45 \%)$, or one calf with two or more adults $(55 \%)$. When swimming, larger dolphins were always ahead of other members of the group, while calves remained in the middle of groups regardless of behavior. In these observations no seasonal differences were observed.

Dolphin presence in Trapandé Bay varied during the day. Group size and behavior also varied with time. From 9:00 a.m. to 10:00 a.m., 60.8\% of the dolphins were seen. Calves $(65.4 \%)$ and juveniles $(58.1 \%)$ were also common during the first hours until 11:00 a.m., though juveniles were absent from 6:00 a.m. to 7:00 a.m.

In $90 \%$ of surveys, dolphins were seen all day long coming into or leaving the estuary area. More dolphins were seen departing than coming into the bay while, in a single day, dolphins were seen only coming in. The majority of specimens entered the bay in decreasing numbers from 7:00 a.m. to 10:00 a.m. From then on, until 5:00 p.m., the opposite trend was observed, whereas from 11:00 a.m. to 12:00 a.m. a greater amount left the study area towards the open sea. After 5:00 p.m., no displacement was observed in any direction. There was no significant correlation between these displacements and daily hours $(r=-0.2065$ entering; $r=-0.0233$ departing) nor with tide $(r=$ -0.2065 entering; $r=-0.023$ departing). When considering the difference line (traced line; Fig. 3 ), more dolphins enter $c a$. one hour before high tide, during all ebb tide and until four hours after low tide. Departing occurred preferentially from four to one hour before high tide (Fig. 3).

\section{Frequency of behavioral patterns}

Field observations allowed the identification of fourteen behavioral patterns: 1-four moving speeds; 2-three fishing modalities; 3-three leap varieties; 4-three modalities of aerial behavior 
(noseout, inverted swimming, and tailslap); 5-and play. The four travelling speeds were: slow, normal (see below), fast, and porpoising. Feeding behaviors were observed in groups or in isolated specimens.

A comparison of behavior patterns showed that dolphins traveled $46.8 \%$ of the time, foraged $33.9 \%$ of the time, and displayed aerial behavior $19.3 \%$ of the time. Only during April and July 1987, more dolphins were fishing than travelling, and leaping. Playing behaviors being the least frequent behavioral pattern all year round. Leaps were not observed during July 1987, and playing was not observed in April, June, July, August and September 1987, when the smallest number of calves was observed. In an analysis with all four seasons, differences were observed in all behavioral patterns (movements: slow (more frequent during winter); $X_{3}^{2}=42.4$, normal (more frequent mainly in the end of winter); $X_{3}^{2}=36.8$, fast (more frequent in summer); $\mathrm{X}_{3}^{2}=14.5$, porpoising (more frequent in winter and summer); $X_{3}^{2}=25.2$, feeding: causal surface fishing (more frequent in summer and fall); $\mathrm{X}_{3}^{2}=18.7$, individual fishing (more frequent in summer); $X_{3}^{2}=62.7$, group fishing (more frequent in the beginning and end of winter); $\mathrm{X}_{3}^{2}=37.7$, leaps (more frequent in spring and summer); $\mathrm{X}_{3}^{2}=$ 61.1, aerial behavior (more frequent in summer and fall); $X_{3}^{2}=21.2$ and play (more frequent in spring); $\left.\mathrm{X}_{3}^{2}=23.4 ; \mathrm{P}<0.05\right)$.

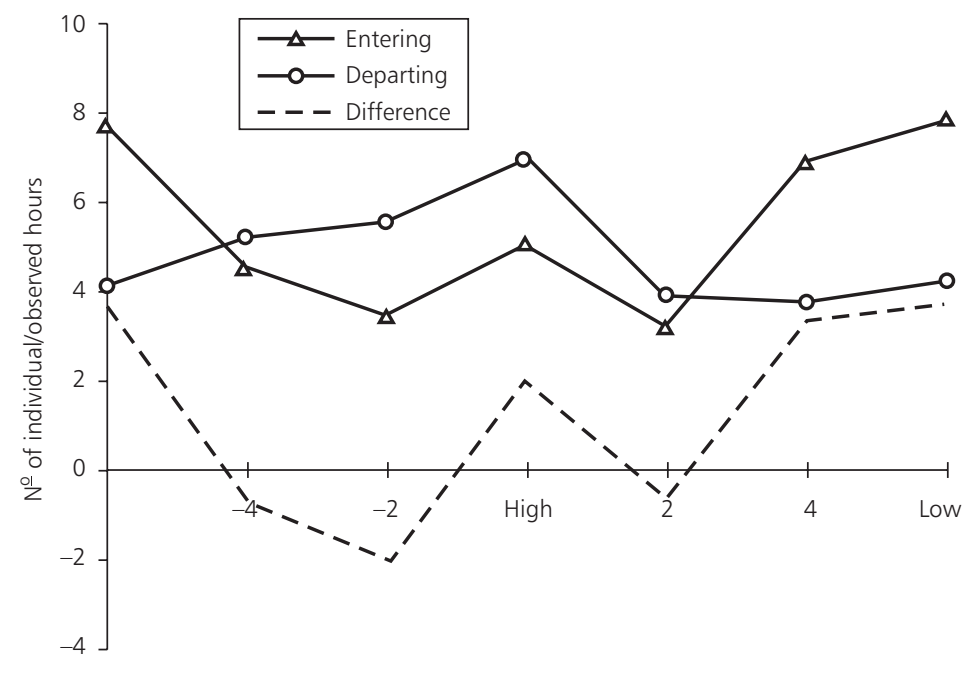

Hours before and after high tide

Fig. 3 - Numbers of entering (triangles) and departing (circles) dolphins according to tide conditions. Traced line represents the difference between entering and departing frequence.

\section{Movement patterns}

During the whole period of study, from 6:00 a.m. to 5:00 p.m., the frequency of travelling dolphins was constant. Only the frequency of fast travel increased gradually, reaching one peak at 11:00 a.m. and another at 4:00 p.m. (Fig. 4). Normal travel was defined as a speed between slow (at resting) and fast travel and porpoising. Normal travel was the most frequently observed and occurred, in the same frequency, at all depths. Slow travel was observed at shore vicinities while fast travel and porpoising were seen exclusively in the middle of channels at greater depths.
During normal travel, the mean dive duration was $20.5 \pm 13.3 \mathrm{~s}$. When calves were present, the duration was $17.7 \pm 21 \mathrm{~s}$; the maximum diving period lasting for $80 \mathrm{~s}$. During slow travel, the maximum period was $127 \mathrm{~s}$ and during resting periods, the average dive duration was $30 \mathrm{~s}$.

\section{Feeding behavior}

The most common feeding behavior was casual surface fishing ( $57 \%$ of all feeding behaviors), observed when group size did not exceed 5 specimens $(96.4 \%)$. This behavior was almost constantly observed in pairs $(40.5 \%)$ or in groups 
of three specimens $(26 \%)$. When foraging in pairs, one individual dived from 3 to $80 \mathrm{~s}$ while the other milled slowly nearby, surfacing in $15 \mathrm{~s}$ diving intervals. The individuals took turns feeding in this manner. This feeding behavior could also be interrupted by periods of motionless floating. These interruptions are likely to be used in the search of additional food supplies. Calves were rarely observed feeding, and they usually stayed in the area where adults re-emerged. This feeding behavior was more frequently observed in shallow areas $(1$ to $3 \mathrm{~m}$ ) from 6:00 a.m. to 7:00 a.m.

Another kind of feeding behavior was very common in shallow areas, or at shores, observed in isolated individuals. Dolphins lie with their flukes and posterior part of their bodies on the sand and their anterior part some way floating on the water. Dolphins remained in this position for a while, displacing laterally the anterior part of their bodies. Suddenly, dolphins "crawl" up and down to enter the water completely and swam rapidly towards the prey. Dolphins would chase the prey at high speed, swimming inverted or on one side. The chase usually lasted for a few seconds (a maximum of $91 \mathrm{~s}$ ) and usually consisted of zigzagging, followed by a short, fast leap (Fig. 5). Isolated dolphins may exhibit this behavior several times a day, remaining in a given area for up to several hours. The dolphin's initiation of the chasing displacement may occur in any direction, more frequently they moved to their right side $(82 \%)$. This feeding behavior occurs up to 5 meters from shore and parallel to the shore line. In beaches of some $500 \mathrm{~m}$ in length, two or three specimens of a same group exhibited this behavior, keeping about 20 meters apart from one another. Not rarely, zigzagging dolphins chased their prey onto the shore, such that the dolphins were completely out of water. Immediately after catching the fish on the sand, they returned to water by crawling in a snake-like way. This behavior was observed throughout the day, though it became considerably more frequent after 5:00 p.m. Juveniles also feed this way.

Feeding in large groups was less frequently observed $(30 \%)$ than casual fishing and it was observed in groups with up to 20 dolphins, that fishes for hours in deeper areas. Group fishing was more frequent prior to 11:00 a.m. Marine birds often flew above and dive in the feeding area. Bird species associated with dolphins were: Sula leucogaster, Larus dominicanus, Fregata magnificens, and Sterna sp.

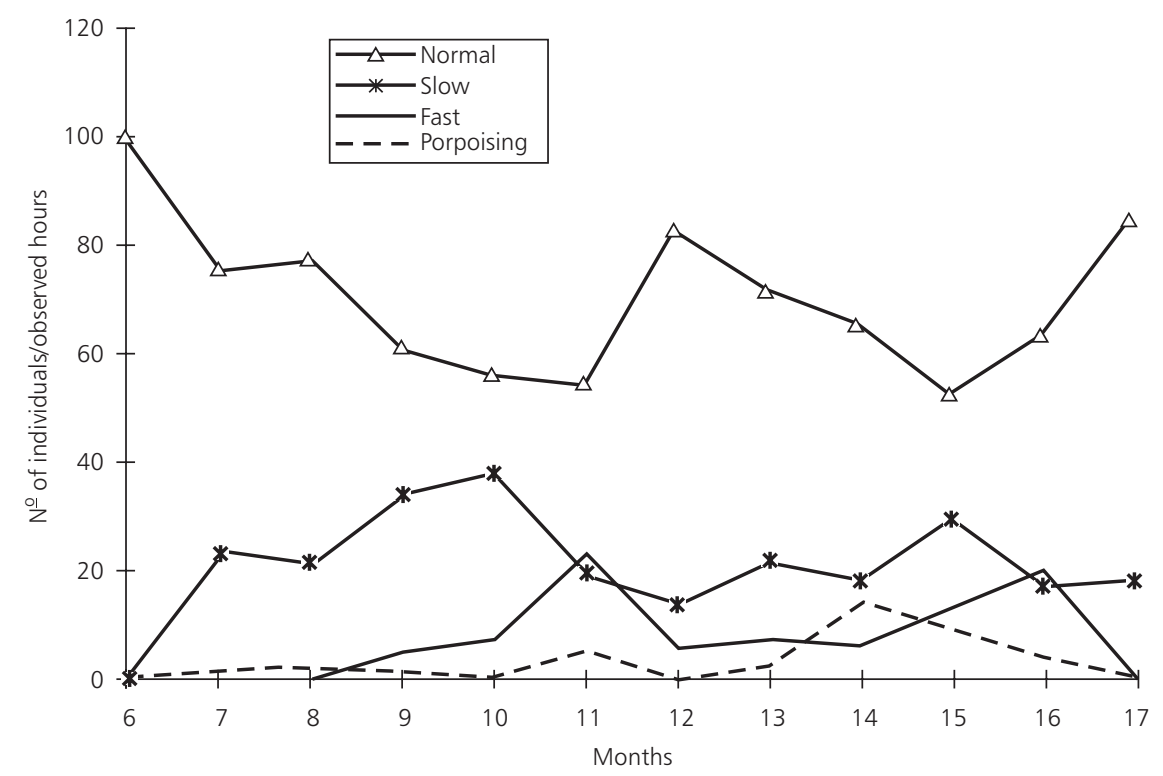

Fig. 4 - Frequency of dolphins engaged in travelling. Fast (black line), normal (triangles), slow (asterisk) and porpoising (dashed line). 


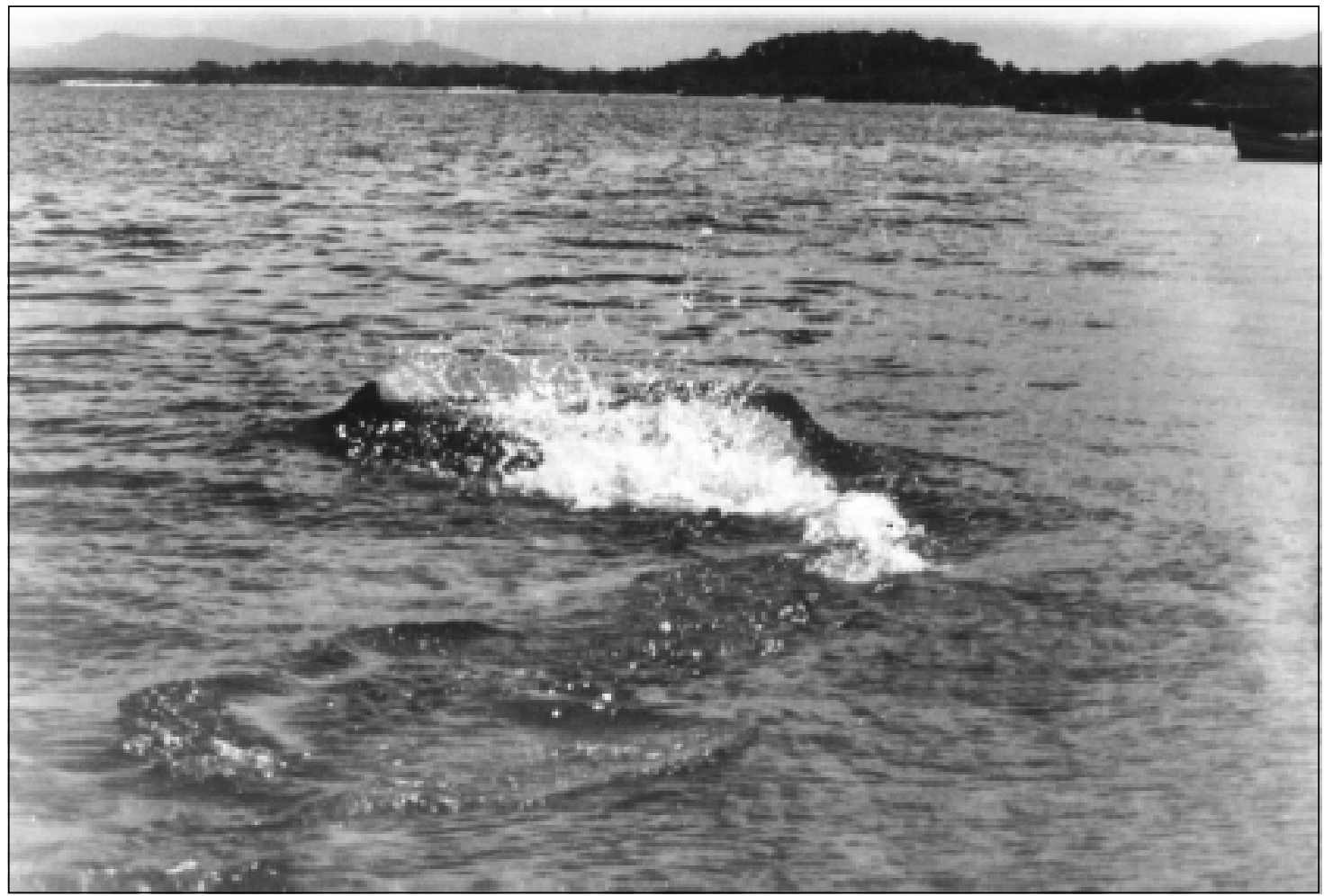

Fig. 5 - Sotalia fluviatilis specimen near shore chasing a prey in high speed, leaving a zigzag shaped wave on water surface.

\section{Aerial behavior}

Leaping was observed at any time of the day and at any distance from shore, less frequently in the morning (37.7\% until 12:00 a.m. and $62.3 \%$ until 6:00 p.m.). In groups with calves and juveniles this behavioral pattern was more frequent. Partial leaping (dolphins rising over the surface with only $3 / 4$ of their body), $34.3 \%$ during the morning, and $65.7 \%$ after midday.

Noseouts were observed only in four months of the study period, more often from 6:00 a.m. to 7:00 a.m. associated with playing and individual feeding behavior, uniquely in groups where calves or juveniles were present.

Inverted swimming (with belly and flippers on the water surface) was also more frequently observed during feeding or playing behaviors, from 8:00 a.m. to 10:00 a.m., and from 12:00 a.m. to 3:00 p.m.

Tailslaps were observed at any distance from shore, often related to feeding behavior. In deeper areas, dolphins raised their tails high above and perpendicular to the water surface before diving.
Calves often slapped their tails during swimming. The frequency of this behavior during the day was correlated to feeding periods $(\mathrm{r}=0.8251 ; \mathrm{P}<0.05)$. Swimming was correlated with feeding behavior $(\mathrm{r}=-0.8671 ; \mathrm{P}<0.05)$. Noseouts and playing behavior were also correlated $(\mathrm{r}=0.8321 ; \mathrm{P}<$ 0.05 ). Other behavioral patterns were not correlated, though headslaps were significantly correlated with the presence of calves $(r=0.7272$; $\mathrm{P}<0.05)$.

\section{Habitat utilization and population size estimates}

Other dolphin species, such as Pontoporia blainvillei and Tursiops truncatus were observed at Praia de Fora (Fig. 1). Sotalia fluviatilis was seen at all sites of the estuary region, but not in the small rivers called "marigôs" (see Occhipinti, 1963), though local fishermen confirmed their presence at high tide.

By following the estimation methods described by Smith (1981), around the Cananéia Island, the calculated population density ( $\hat{D})$ was $3.38 \pm$ 1.76 individuals $/ \mathrm{km}^{2}$ within an estimated mean line 
transect-width of $0.14 \mathrm{~km}$, considering that dolphins were not homogeneous distributed in this area (Fig. 1). From this estimate, dolphin abundance $(\mathrm{N})$ was found to be $704.8 \pm 367.7$ along the $82 \mathrm{~km}$ transect. The short line transects between Cananéia and Cardoso Islands had a transect width of $0.2 \mathrm{~km}$. Densities ( $\hat{D}$ ) were $12.4 \pm 10.3$ individuals $/ \mathrm{km}^{2}$ in the morning and $16.4 \pm 13.8$ individuals $/ \mathrm{km}^{2}$ in the afternoon, respectively. Estimated $\mathrm{N}$ values equaled $456 \pm 379.3$ individuals in the morning and $602.4 \pm 506.8$ individuals in the afternoon. In this restricted part of the study area, dolphins present an homogeneous distribution (Fig. 1).

\section{DISCUSSION}

As observed at Guanabara Bay with the same methodology used here (Geise, 1991), dolphins (Sotalia fluviatilis) were present throughout the year. They occupied the whole estuary region but with a preference to the Trapandé Bay area, with very shallow areas (less than one meter) to the deepest areas found (Fig. 1), unlike Guanabara Bay dolphins, which preferentially concentrate only in deeper areas. Although the present study area is situated in the most populated region in Southeast Brazil, few human activities were observed around Cananéia. The absence of intensive boat traffic or direct polluting sources' results in an environment very different and better preserved from others nearby. There are also some considerations about the used methodology. Just one observer performed the field work, and, in trying to minimize a possible sub estimation that could be caused by a visual tiredness of the observer. The same must be considered for those results with juveniles and calves.

Normal travel was the most common behavior seen in Cananéia. Such a behavior was described as being apparently similar in other dolphin species, as for example Phocoenoides dalli (Jefferson, 1987) and Tursiops truncatus (Würsig \& Würsig, 1979). Slow travel was frequently observed during feeding behavior and resting near shore. Layne (1958) described this behavior, noting that this movement was slow, as if dolphins (Inia geoffrensis \& S. fluviatilis) remained still in order to breathe. Loeb (1972) and Morejohn (1979) interpreted slow travel as a sleeping period, while Würsig (1979) postulated that stillness allowed dolphins ( $T$. truncatus) to obtain more refined hearing stimuli. Fast travel and porpoising were not very common in Cananéia. Fast travel occurred more frequently at midday and dawn, in larger groups, as observed in the Guanabara Bay (Geise, 1991). As Lagenorhynchus obscurus, in San José Gulf (Argentina), S. fluviatilis was more active during the afternoon, when moving to the open sea (Würsig \& Würsig, 1980). Thus, a similar movement behavior pattern was observed in the Guanabara Bay, Rio de Janeiro (Geise, 1991) and in Cananéia. Swimming speed increased in deeper areas (of more than 10 meters), as reported by Würsig \& Würsig (1980).

Group feeding was more frequent in the morning, when larger groups were present. S. fluviatilis mainly preys on shoal-forming fish species (Borobia, 1984; Silva, 1983; Simões-Lopes, 1988; Borobia \& Barros, 1989; Silva \& Best, 1994).

Casual surface fishing, common at the early hours and during the afternoon, occurred at similar periods in S. fluviatilis (Silva \& Best, 1994). As with $S$. fluviatilis in the Guanabara Bay (Andrade et al., 1987), casual surface fishing was observed in shallow areas. Group feeding, contrary to casual surface fishing, was more frequent during April, June, and September 1987 and during the first observation period in January 1988. During April and June 1987 it may be related to the abundance of mullets (Mugilidae; Mesquita, 1978), a shoalforming fish species they feed on (see below).

The inverted swimming behavior observed in Cananéia was similar to that observed in the freshwater form (Borobia, 1984), and in Cephalorhynchus commersonii (Evans \& Cornell, 1985), and has been related to reproductive behavior (Saayman et al., 1973; Taylor \& Saayman, 1973; Payne, 1976) or, to the ability of detecting benthonic pray (Evans \& Cornell, 1985). A survey of $S$. fluviatilis feeding habits (Carvalho, 1963; Borobia, 1984; Simões-Lopes, 1988; Siciliano et al., 1988; Schmiegelow, 1990) indicates that this species mainly feeds upon coastal fishes that are common to areas with muddy or sandy underwater bottoms.

S. fluviatilis, different as Tursiops truncatus, for example, as observed in other areas of their distribution range (Borobia, 1988; Andrade et al., 1987; Simões-Lopes, 1988; Geise, 1991 and personal observation - L. Geise), did not show any 
kind of interaction with boats or human activities, not approximating nor shoving off.

Associations with bird species during feeding behavior in this same area were also reported by Monteiro-Filho (1992) who, in addition to the species herewith reported, also found Phalacrocorax olivaceus. Birds probably disrupt fish shoals they are feeding on, hence interacting with feeding dolphins.

Diurnal migrations are common in many cetaceans (Delany, 1982). As observed in the Guanabara Bay, where $S$. fluviatilis enters the Bay probably to feed (Geise, 1991), in the Cananéia estuary region, the high estimated density can be explained when this area is considered as a special feeding place or as a refuge, where calm waters provides protection against predators. Estimated densities in Cananéia and Guanabara Bay (Geise, 1991) were similar. The higher estimate for Trapandé Bay, the largest part of the estuary system (Fig. 1) can be understood, as this area consists of the main entrance for this protected area and probably also provides enough feeding supplies. All densities here obtained were also higher than the one observed for S. fluviatilis in the Solimões River, in the Amazon basin (Magnusson et al., 1980). These higher densities in Cananéia can be explained if this population was considered as a resident population, or the whole estuary area as a feeding concentration area during the day, with nocturnal migration.

Acknowledgements - We thank especially Maria Martha A. de Oliveira for the bird species identification. Fernando Rosas, Maria Elizabeth de Araujo and Hector Seuánez for helpful comments. The Coordenadoria de Aperfeiçoamento de Pessoal de Nível Superior, Federal Government, Brazil (CAPES personal fellowship to L. Geise), and partially Bertha Reichardt financed the research. The Instituto Oceanográfico, Universidade de São Paulo (IO-USP) provided support for field work.

\section{REFERENCES}

ANDRADE, L., SICILIANO, S. \& CAPISTRANO, L., 1987, Movimentos e atividades do boto Sotalia guianensis (Cetacea, Delphinidae) na Baía de Guanabara. Reunião de Trabalho de Especialistas em Mamíferos Aquáticos da América do Sul, 2. Anais, Rio de Janeiro, Fundação Brasileira para a Conservação da Natureza, pp. 41-56.

BOROBIA, M., 1984, Comportamento e aspectos biológicos dos botos da Baía de Guanabara, Sotalia sp. Rio de Janeiro, Universidade do Estado do Rio de Janeiro, 81p.

BOROBIA, M. \& BARROS, N. B., 1989, Notes on the diet of marine Sotalia fluviatilis. Marine Mammal Science, 5(4): 395-398.
BOROBIA, M., SICILIANO, S., LODI, L. \& HOEK, W., 1991, Distribution of the South American dolphin Sotalia fluviatilis. Can. J. Zool., 69: 1025-1039.

CARVALHO, C. T. de, 1963, Sobre o boto comum no litoral do Brasil (Cetacea, Delphinidae). Rev. Brasil. Biol., 23(3): 263-276.

DELANY, M. J., 1982, Mammal Ecology. East Kilbride, Thomsom Litho, vii, 162p.

EVANS, W. E. \& CORNELL, L. H., 1985, Natación invertida en un delphin commerson: muestra de cortejo o inspección del fondo con el sonar? Annual Conference of the International. Marine Animal Trainers Association (IMATA), 13, Florida, p. 61.

GEISE, L., 1991, Sotalia guianensis (Cetacea, Delphinidae) population in the Guanabara Bay, Rio de Janeiro, Brazil. Mammalia, 55(3): 371-379.

JEFFERSON, T. A., 1987, A study of the behavior of Dall's porpoise (Phocoenoides dalli) in the Johnstone Strait, British Columbia. Can. J. Zool., 65: 736-744.

LAYNE, J. N., 1958, Observations on freshwater dolphins in the upper Amazon. J. Mamm., 39(1): 1-21.

LEHNER, P. N., 1979, Handbook of ethological methods. Garland STPM Press, New York and London, 402p.

LOEB, V. J., 1972, A study of the distribution and feeding of the Dall Porpoise in Monterey Bay, California. California, San José State University, California, 62p.

MAGNUSSON, W. E., BEST. R. C. \& DA SILVA, V. M. F., 1980, Number and behavior of Amazonian dolphins, Inia geoffrensis and Sotalia fluviatilis in the Rio Solimões, Brasil. Aquatic Mammals, 8(1): 27-32.

MESQUITA, H. de S. L., 1978, Taxa de consumo de oxigênio pelo plâncton nas águas de superfície na região de Cananéia (22S48W), Estado de São Paulo. São Paulo, Universidade de São Paulo, Ph.D. Thesis, 244p.

MONTEIRO-FILHO, E. L. A., 1992, Pesca associada entre golfinhos e aves marinhas. Rev. Brasil. Zool., 9(1/2): 2937.

MOREJOHN, V., 1979, The natural history of Dall's porpoise in the North Pacific Ocean. In: H. E. Winn \& B. L. Olla (eds.), Behavior of marine animals: Cetaceans, New York, Plenum Press, v. 3, pp. 45-81.

OCCHIPINTI, A. G., 1963, Climatologia dinâmica do litoral sul brasileiro. Contribuições do Instituto Oceanográfico, Sér. Oceanogr. Física, São Paulo, 3: 1-86.

PAYNE, R., 1976, At home with right whales. Natl. Geographic, 149(3): 322-339.

SAAYMAN, G. S., TAYLER, C. K. \& BOWER, D., 1973, Diurnal activity cycles in captive and free-ranging Indian Ocean bottlenose dolphins (Tursiops aduncus Ehrenburg). Behavior, 44(3/4): 212-233.

SCHMIEGELOW, J. M. M., 1990, Estudo sobre cetáceos odontocetes encontrados em praias da região entre Iguape (SP) e Baía de Paranaguá (PR) $\left(24^{\circ} 42^{\prime} S-25^{\circ} 28^{\prime} S\right)$ com especial referência a Sotalia fluviatilis (Gervais, 1853) (Delphinidae). Universidade de São Paulo, Master of Science Dissertation, 149p. 
SICILIANO, S., CAPISTRANO, L. \& Lodi, L., 1988, Xenobalanus globicipitis registrado em Sotalia sp. na Baía de Guanabara, Rio de Janeiro, Brasil. Reunión de Trabajo de Especialistas en Mamíferos Acuaticos de América del Sur, 3ạ, Montevidéo, Uruguai. Resumos, Montevidéo, Museo Nacional de Historia Natural, p. 18.

SILVA, V. M. F. da, 1983, Ecologia alimentar dos golfinhos da Amazônia. Manaus, Fundação Universidade do Amazonas e Instituto Nacional de Pesquisas da Amazônia. Master of Science Dissertation, 118p.

SILVA, V. M. F. da \& BEST, R. C., 1994, Tucuxi Sotalia fluviatilis (Gervais, 1853). In: S. H. Ridgway \& R. Harrison (eds.), Handbook of marine mammals, v. 5, Academic Press, pp. 43-69.

SILVA, V. M. F. da \& BEST, R. C., 1996, Sotalia fluviatilis. Mammalian Species, 527: 1-7.

SIMÕES-LOPES, P. C., 1988, Ocorrência de uma população de Sotalia fluviatilis (Gervais, 1853) (Cetacea, Delphinidae) no limite sul de sua distribuição, Santa Catarina, Brasil. Biotemas, 1(1): 57-62.
SMITH, T. D., 1981, Line-transect techniques for estimating density of porpoises schools. Journal of Wildlife Management, 45(3): 650-657.

TAYLOR, C. K. \& SAAYMAN, G. S., 1973, Imitative behavior by Indian Ocean bottlenose dolphins (Tursiops truncatus) in captivity. Behavior, 44(3/4): 286-296.

WÜRSIG, B., 1979, Dolphins. Scientific American, 240(3): 136-148.

WÜRSIG, B. \& WÜRSIG, M., 1979, Behavior and ecology of the bottlenose dolphin, Tursiops truncatus, in the South Atlantic. Fishery Bulletin, 77(2): 399-412.

WÜRSIG, B. \& WÜRSIG, M., 1980, Behavior and ecology of the dusky dolphin, Lagenorhynchus obscurus, in the South Atlantic. Fishery Bulletin, 77(4): 871-890.

ZAR, J. H., 1984, Biostatistical analysis. Prentice-Hall, Inc., New Jersey, 718p. 